\title{
Soybean productivity with Trichoderma asperellum seed treatment in different regions of the Brazilian Cerrado
}

\author{
Aloisio Freitas Chagas Junior ${ }^{1 *}\left(\mathbb{D}\right.$, Lillian França Borges Chagas ${ }^{1} \oplus$, \\ Albert Lennon Lima Martins ${ }^{1} \oplus$, Brigitte Sthepani Orozco Colonia ${ }^{\circledR}$, Rodrigo Silva de Oliveira ${ }^{1} \mathbb{0}$ \\ 1 Universidade Federal do Tocantins, Brasil. Gurupi, TO, Brasil. E-mail: chagasjraf@uft.edu.br; lillianfbc@uft.edu.br; eng.albertlennon@gmail.com; d.rigo.oliveira@hotmail.com
2 Universidade Federal do Paraná, Curitiba, PR, Brasil. E-mail: bricolonia@gmail.com
}

ABSTRACT: The purpose of this study was to evaluate the efficiency of the product containing Trichoderma asperellum 201 in soybean field productivity in different regions of the Brazilian Cerrado. Thirty-five experiments were conducted in the states of Bahia and Tocantins, in different municipalities, in the 2017/2018, 2018/2019 and 2019/2020 seasons. The treatments used were the seed treatment with $T$. asperellum and a control (without inoculation of Trichoderma). The seeds were inoculated (TS) with product containing $T$. asperellum, at a dose of $5 \mathrm{~g}$ per kg of seeds, formulated with a minimum concentration of $2 \times 10^{8}$ CFU g ${ }^{-1}$, with graphite as an inert material in the formulation. In all fields in the states of Bahia and Tocantins, positive effects $(p<0.05)$ of inoculation of the $T$. asperellum were observed in the productivity of different soybean cultivars. In the Bahia state fields, productivity gains varied between seasons, with an average productivity gain of $8.01 \%$ seen for the $2017 / 2018$ crop, $3.97 \%$ for the $2018 / 2019$ crop, and $9.23 \%$ for the $2019 / 2020$ crop. In Tocantins, the average productivity, considering all experiments, was $13.02 \%$.

Key words: fungus; Glycine max (L.) Merrill; plant growth promoter; productions

\section{Produtividade da soja inoculada com Trichoderma asperellum em diferentes regiões do Cerrado, Brasil}

RESUMO: O objetivo deste estudo foi avaliar a eficiência do produto contendo Trichoderma asperellum 201 na produtividade da soja em diferentes regiões do Cerrado brasileiro. Foram realizados 35 experimentos nos estados da Bahia e Tocantins, em diferentes municípios, nas safras 2017/2018, 2018/2019 e 2019/2020. Os tratamentos utilizados foram o tratamento de sementes com T. asperellum e um controle (sem inoculação de Trichoderma). As sementes foram inoculadas (TS) com produto contendo $T$. asperellum, na dose de $5 \mathrm{~g}$ por kg de sementes, formulado com concentração mínima de $2 \times 10^{8} \mathrm{UFC}^{-1}$, tendo grafite como material inerte na formulação. Em todas as regiões dos estados da Bahia e Tocantins, foram observados efeitos positivos $(p<0,05)$ da inoculação de $T$. asperelum na produtividade de diferentes cultivares de soja. Para o estado da Bahia, os ganhos de produtividade variaram entre as safras, com ganho de produtividade médio de $8,01 \%$ na safra $2017 / 2018,3,97 \%$ na safra 2018/2019 e 9,23\% na safra 2019/2020. Para o Tocantins, a produtividade média, considerando todos os experimentos, foi de $13,02 \%$.

Palavras-chave: fungo; Glycine max (L.) Merrill; promotor de crescimento de planta; productions

\footnotetext{
*Aloisio Freitas Chagas Junior - E-mail: chagasjraf@uft.edu.br (Corresponding author)

Associate Editor: Mário de Andrade Lira Júnior
} 


\section{Introduction}

Soybean (Glycine max (L.) Merrill) production is one of the economic activities that has grown the most in recent years in Brazil (Sousa \& Bittencourt, 2019). Represents the main Brazilian agricultural commodity, its importance in the economy is since Brazil is the largest exporter of the complex (grain, bran, and oil) and the first world producer (Conab, 2018).

The Matopiba region is an extremely important agricultural frontier in Brazil. Over the past ten years, Matopiba has accounted for almost $10 \%$ of the country's grain production, and its three main products - soybeans, corn and cotton - have at least doubled their production in this period (Input, 2021; Embrapa, 2021).

The increase in the world's population and climate change represents a challenge for global agricultural production. There is a need to intensify agricultural production in a sustainable way and find solutions to combat abiotic stress, pathogens, and pests.

Plants are associated with complex microbiomes, which can be defined as the set of genes found in association with organisms that colonize a given environment (Murillo-Cuevas et al., 2019). Growth-promoting microorganisms can be useful to mitigate modern agriculture challenges in the coming years that aim to increase sustainable food production, with proper environmental protection (Ferreira, 2018).

The microbiome potentially to promote plant growth and vegetable organism tolerance to phytopathogen parasitism and may represent a promising sustainable solution to improve crop yield. Among the several microorganisms found naturally in the soil, fungal species of the Trichoderma genus figure out as the most studied and a are known components of biofungicides (Karaoglu et al., 2018; Alekseeva et al., 2019).

The Trichoderma species are classified as saprophytes, free-living that can live both in the soil, especially in tropical regions, eventually endophytic, with asexual reproduction, having their importance beeing proven for use in agriculture. They are usually studied as biocontrol agents (Monte et al, 2019; Ramada et al., 2019; Pascholati et al., 2019) and present plant growth promoting activities (Das et al., 2017; Woo \& Pepe, 2018; Mendoza-Mendoza et al., 2018). In plants, some Trichoderma strains produce secondary metabolites such as 3 -indoleacetic acid (IAA), which acts in promoting the growth of vegetative parts (Chagas et al., 2017a).

T. asperellum has been reported as a plant growth promoter through its phosphate solubilization capacity and indole acetic acid (IAA) synthesis, with a positive effect on increasing biomass, nitrogen content, nodulation and productivity, using granulated formulation (Chagas Junior et al., 2019a,b).

The promotion of plant growth by the action of Trichoderma is complex and involves biochemical processes, enzyme production (Monte et al., 2019; Ramada et al., 2019), production of hormones and growth factors, besides the provision of nutrients, mainly phosphates. The ability of such microorganisms to perform phosphate solubilization has been adopted to replace or reduce the use of soluble phosphate fertilizers (Chagas et al., 2017a; Bononi et al., 2020).

Brazil has a huge potential for production and use of inoculants and biopesticides, however, among the aspects that justify the low exploration of this sector, is the limited availability of commercial products based on Trichoderma legally registered in the Ministry of Agriculture, Livestock and Supply - MAPA (Agrofit). Even though in recent years legal regulations have promoted a broader adequacy of these products in relation to conventional chemicals, important limitations still remain, such as: isolated with poor adaptation to different agroecosystems (Bernardo et al., 2019), as well as formulations more appropriate for use in seed inoculation.

Seeds can be treated with different products, such as chemicals, fungicides, and insecticides, and formulated based on fungi and bacteria for biological control and promotion of plant growth. The use of Trichoderma-based formulas for seed treatment has been widely studied, being used as a biocontrol agent and to promote plant growth. There are different formulations based on Trichoderma in the national and international market that are used according to the purpose of the treatment, highlighting the seed treatment considered less costly and more effective.

Therefore, the objective of this work was to evaluate the efficiency of the Trichoderma asperellum, in powder formulation, on soybean productivity in the field, in different regions.

\section{Materials and Methods}

Thirty-five experiments were conducted in the Brazilian states of Bahia and Tocantins, in different municipalities, in the seasons of $2017 / 2018,2018 / 2019$ and 2019/2020, in the period from october to march, with different edaphoclimatic conditions, in Macro-regions 4 (Edaphoclimatic Region 404: Municipalities of Cariri, Crixas, Gurupi, Ipueiras, Jaú do Tocantins and Formoso do Araguaia, Tocantins; edaphoclimatic region 405: Municipalities of Barreiras, Correntina, Formoso do Rio Preto, Luiz Eduardo Magalhães and São Desidério, Bahia) and 5 (edaphoclimatic regions 501: Municipalities: Bom Jesus, Santa Maria, Fortaleza do Tabocão, Darcinópolis, Piraquê, Barrolândia and Porto Nacional, Tocantins) (Normative Instruction $\mathrm{N}^{\circ} 1$ (Brazil, 2012a,b)), according to the locations in Table 1 and Figure 1.

In the areas where the experiments were installed, the experimental plots had a minimum of nine planting lines, 6.0 $x 4.0 \mathrm{~m}$, and $0.5 \mathrm{~m}$ of spacing between the planting lines.

In the different areas where the experiments were implemented, fertilization followed the recommendations for the different locations and harvest, being carried out by the owners of the areas, using different chemical fertilizers and formulations.

Different soybean cultivars were used, chosen by the farms. In all experiments the seeds were chemically treated with different fungicides and insecticides, with a product based on methyl thiophanate and fipronil, as recommended 
Table 1. Location and weather conditions of the different experiments with Trichoderma asperellum in soybean seeds treatment.

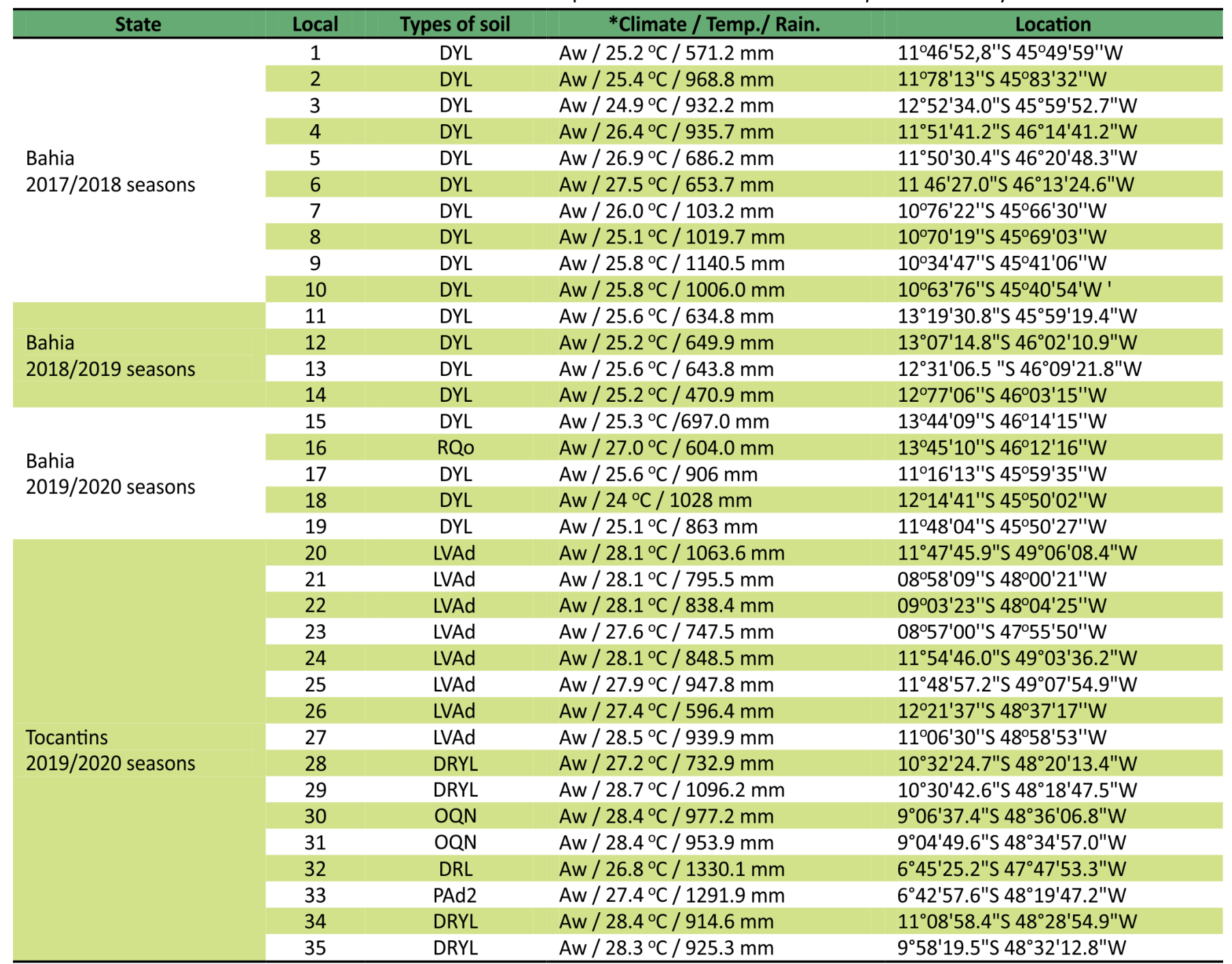

*Weather stations near each region: INMET (2021) and Agritempo (2021). Climate according to Köppen e Geiger. Temp. = Average temperature for the period. Rain. $=$ Average rainfall for the period. DYL = Dytrophic Yellow Latosol. DRL = Dytrophic Red Latosol. DRYL $=$ Dystrophic Red Yellow Latosol. RQo = Ortic Quartzrenic Neosol. YU2 $=$ Yellow Ultisol 2.

STATE OF TOCANTINS, BRAZIL

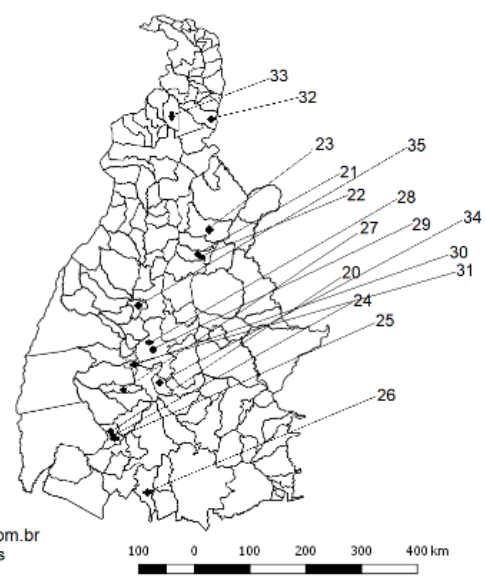

STATE OF BAHIA, BRAZIL

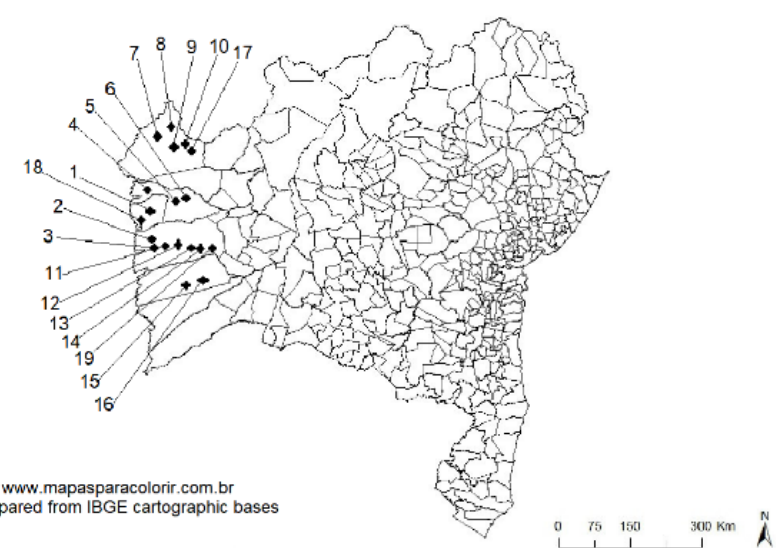

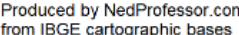

Figure 1. Distribution of experiments in the states of Tocantins and Bahia, Brazil.

by the manufacturers. In all experiment's soybean seeds were previously inoculated with rhizobium, with bacteria belonging to the species Bradyrhizobium japonicum (SEMIA 5079 and SEMIA 5080), using dosages according to the recommendations of the manufacturers, ranging from 400 to $500 \mathrm{~mL}$ per ha.

The T. asperellum 201 strain was isolated from Cerrado soil in Tocantins. A preliminary identification was made according 
to the morphological characteristics based on specialized bibliography and with the aid of an optical microscope. Then, the genetic characterization was performed by sequencing the TEF (translation elongation factor) region and identified by the access codes in GenBank (Species Identification: T. asperellum GJS 04-217; GenBank access: DQ381958; Similarity: 99\%).

The treatments used were the seed inoculation of Trichoderma asperellum 201 and an absolute control (without inoculation of Trichoderma). The seeds were inoculated with T. asperellum 201, at a dose of $5 \mathrm{~g}$ per $\mathrm{kg}$ of seeds, formulated with a minimum concentration of $2 \times 10^{8} \mathrm{CFU} \mathrm{g}^{-1}$, with graphite as an inert in the formulation. The $T$. asperellum was mixed in the seeds on the day of planting, after the inoculation of rhizobium, being made in a seed mixing inoculator.

All the experiments had a random blocks design with four repetitions. During the crop development, all the necessary phytotechnical and phytosanitary management were done as recommended by Henning (2009).

Grain production was obtained in the four central lines rows of each plot with a useful area of $10 \mathrm{~m}^{2}$, after the physiological maturation of the plants. The harvest was carried out manually, harvesting all the plants from the useful area, and the grains were processed in threshing machines, adjusting the grains moisture to $13 \%$. Afterwards, the productivity was estimated in kg per hectare.

The hypothesis of equality between the means of the two treatments evaluated was made by the $F$ test of the analysis of variance for $p=0.05$, using the SISVAR statistical program (Ferreira, 2019). Comparison of means was performed only at inoculation or not within each experiment, with no comparison between places or seasons.

\section{Results and Discussion}

\section{Bahia 2017/2018}

In the experiments in Bahia, 2017/2018 crop, in all treatments with $T$. asperellum the productivity was significantly higher $(p<0.05)$ compared to the control without inoculation (Table 2). In these different areas, productivity gains ranged from 3.37 to $21.49 \%$ in relation to non-inoculation control, with an average increase in productivity, in relation to control treatment, of $8.01 \%$

\section{Bahia 2018/2019}

For the 2018/2019 crop, in all treatments with T. asperellum the productivity was significantly higher $(p<0.05)$ compared to the control without inoculation (Table 3 ). In these different areas productivity gains ranged from 2.28 to $5.04 \%$ compared to the control without inoculation, with the average increase in productivity compared to the control treatment being $3.97 \%$.

\section{Bahia 2019/2020}

For the 2019/2020 crop, in all treatments with T. asperellum the productivity was significantly higher $(\mathrm{p}<0.05)$ compared to the control without inoculation (Table 4). In these different areas, the productivity gains ranged from 1.89 to $25.55 \%$ in relation
Table 2. Soybean productivity with Trichoderma asperellum in seeds treatment, in different localities in Bahia, Brazil, 2017/2018 season ${ }^{1}$.

\begin{tabular}{|c|c|c|c|}
\hline Location & Cultivar & Treatments & $\begin{array}{c}\text { Productivity } \\
\left(\mathrm{kg} \mathrm{ha}^{-1}\right)\end{array}$ \\
\hline \multirow{3}{*}{1} & \multirow{3}{*}{ M 8349 ipro } & T. asperellum & $4100 \mathrm{a}$ \\
\hline & & Control & $3750 \mathrm{~b}$ \\
\hline & & $\mathrm{CV}(\%)^{2}$ & 1.32 \\
\hline \multirow{3}{*}{2} & \multirow{3}{*}{ M 8349 ipro } & T. asperellum & 4227 a \\
\hline & & Control & $3891 b$ \\
\hline & & CV (\%) & 1.21 \\
\hline \multirow{3}{*}{3} & \multirow{3}{*}{ M 8349 ipro } & T. asperellum & $5606 a$ \\
\hline & & Control & $5369 \mathrm{~b}$ \\
\hline & & CV (\%) & 0.75 \\
\hline \multirow{3}{*}{4} & \multirow{3}{*}{ M 8349 ipro } & T. asperellum & 5157 a \\
\hline & & Control & $4989 \mathrm{~b}$ \\
\hline & & CV (\%) & 0.77 \\
\hline \multirow{3}{*}{5} & \multirow{3}{*}{ M 8372 ipro } & T. asperellum & 4037 a \\
\hline & & Control & $3323 b$ \\
\hline & & CV (\%) & 2.03 \\
\hline \multirow{3}{*}{6} & \multirow{3}{*}{ M 8372 ipro } & T. asperellum & $2828 a$ \\
\hline & & Control & $2678 b$ \\
\hline & & CV (\%) & 1.47 \\
\hline \multirow{3}{*}{7} & \multirow{3}{*}{ M 8349 ipro } & T. asperellum & 4460 a \\
\hline & & Control & $4217 \mathrm{~b}$ \\
\hline & & CV (\%) & 1.06 \\
\hline \multirow{3}{*}{8} & \multirow{3}{*}{ M 8349 ipro } & T. asperellum & 3860 a \\
\hline & & Control & $3633 b$ \\
\hline & & CV (\%) & 1.09 \\
\hline \multirow{3}{*}{9} & \multirow{3}{*}{ M 8349 ipro } & T. asperellum & 4447 a \\
\hline & & Control & $4146 b$ \\
\hline & & CV (\%) & 0.99 \\
\hline
\end{tabular}

'Means followed by the same small letter, in the columns, for each location/experiment, do not differ between themselves by the $\mathrm{F}$ test at $5 \% .{ }^{2}$ Coefficient of variation.

Table 3. Productivity of soybean with Trichoderma asperellum in seeds treatment, in different locations in Bahia, Brazil, 2018/2019 season $^{1}$.

\begin{tabular}{cccc}
\hline Location & Cultivar & Treatments & $\begin{array}{c}\text { Productivity } \\
\left(\mathbf{k g ~ h a}^{-1}\right)\end{array}$ \\
\hline \multirow{2}{*}{10} & \multirow{2}{*}{ Dow 5G8015 ipro } & T. asperellum & $4673 \mathrm{a}$ \\
& & Control & $4472 \mathrm{~b}$ \\
& \multirow{3}{*}{11} & CV (\%) & 0.71 \\
& \multirow{2}{*}{ FTR 3178 ipro } & T. asperellum & $4541 \mathrm{a}$ \\
& & Control & $4323 \mathrm{~b}$ \\
\multirow{2}{*}{12} & \multirow{2}{*}{ CD 2851 ipro } & CV (\%) & 0.77 \\
& & T. asperellum & $4078 \mathrm{a}$ \\
& & Control & $3899 \mathrm{~b}$ \\
\multirow{2}{*}{13} & CD 2851 ipro & C. asperellum & $5706 \mathrm{a}$ \\
& & Control & $5579 \mathrm{~b}$ \\
& & CV (\%) & 0.19 \\
\hline
\end{tabular}

'Means followed by the same small letter, in the columns, for each location/experiment, do not differ between themselves by the $\mathrm{F}$ test at $5 \% .{ }^{2}$ Coefficient of variation.

to the control without inoculation, with the average increase in productivity, in relation to the control treatment, of $9.23 \%$

\section{Tocantins 2019/2020}

For the 2019/2020 crop, in Tocantins, in all treatments with $T$. asperellum the productivity was significantly higher 
Table 4. Productivity of soybean with Trichoderma asperellum in seeds treatment, in different locations in Bahia, Brazil, 2019/2020 season $^{1}$.

\begin{tabular}{|c|c|c|c|}
\hline Location & Cultivar & Treatments & $\begin{array}{l}\text { Productivity } \\
\left(\mathrm{kg} \mathrm{ha}^{-1}\right)\end{array}$ \\
\hline \multirow{3}{*}{14} & \multirow{3}{*}{ FTR 2128 ipro } & T. asperellum & $4160 \mathrm{a}$ \\
\hline & & Control & $4065 b$ \\
\hline & & CV $(\%)^{2}$ & 0.87 \\
\hline \multirow{3}{*}{15} & \multirow{3}{*}{ FTR 2128 ipro } & T. asperellum & 4298 a \\
\hline & & Control & $4218 b$ \\
\hline & & CV (\%) & 0.67 \\
\hline \multirow{3}{*}{16} & \multirow{3}{*}{ M 8349 ipro } & T. asperellum & 4725 a \\
\hline & & Control & $4507 b$ \\
\hline & & CV (\%) & 0.56 \\
\hline \multirow{3}{*}{17} & \multirow{3}{*}{ M 8349 ipro } & T. asperellum & 2449 a \\
\hline & & Control & $2196 b$ \\
\hline & & CV (\%) & 2.30 \\
\hline \multirow{3}{*}{18} & \multirow{3}{*}{ M 8349 ipro } & T. asperellum & 3871 a \\
\hline & & Control & $3084 b$ \\
\hline & & CV (\%) & 3.48 \\
\hline \multirow{3}{*}{19} & \multirow{3}{*}{ M 8349 ipro } & T. asperellum & $3794 a$ \\
\hline & & Control & $3603 b$ \\
\hline & & CV (\%) & 1.05 \\
\hline
\end{tabular}

'Means followed by the same small letter, in the columns, for each location/experiment, do not differ between themselves by the $\mathrm{F}$ test at $5 \%{ }^{2}$ Coefficient of variation.

( $p<0.05$ ) compared to the control without inoculation (Table $5)$. In these different areas, productivity gains ranged from 7.37 to $29.46 \%$ in relation to the control without inoculation, with an average increase in productivity, in relation to control treatment, of $13.02 \%$

In all regions in the State of Bahia and Tocantins, positive effects of inoculation of the $T$. asperellum were observed in the productivity of different soybean cultivars. Regarding the Bahia state, productivity gains varied between seasons, with an average productivity gain of $8.01 \%$ for the $2017 / 2018$ crop, $3.97 \%$ for the $2018 / 2019$ crop, and $9.23 \%$ for the $2019 / 2020$ crop. For Tocantins the average productivity, considering all the experiments, was $13.02 \%$. These increases in productivity would lead to possible economic gains with increased productivity.

The positive responses for productivity, in different regions and different soybean cultivars, ware related to the ability of the fungus Trichoderma to promote vegetable growth through different mechanisms, such as the production of phytohormones and nutrient solubilization capacity (Chagas et al., 2017c; Bononi et al., 2020). These effects can bring improve in plant development, increase of seedling emergence rate, root system, aerial part, chlorophyll content, size and/ or number of flowers and/or fruits (Mendoza-Mendoza et al., 2018). The positive effects of Trichoderma on roots increase the absorption area, favoring the nutrient use efficiency, which consequently improve yields.

The growth promotion effect is also attributed to the role of Trichoderma to solubilize phosphates and micronutrients, mediated by the release of siderophores and secondary metabolites, or by modifications in the content of ethylene and auxins which stimulate plant development (Silva et al., 2019).
Table 5. Productivity of soybean with Trichoderma asperellum in seeds treatment, in different locations in Bahia, Brazil, 2019/2020 season ${ }^{1}$.

\begin{tabular}{|c|c|c|c|}
\hline Location & Cultivar & Treatments & $\begin{array}{l}\text { Productivity } \\
\left(\mathrm{kg} \mathrm{ha}^{-1}\right)\end{array}$ \\
\hline \multirow{3}{*}{20} & \multirow{3}{*}{ CZ 58B28 } & T. asperellum & $4004 \mathrm{a}$ \\
\hline & & Control & $3694 \mathrm{~b}$ \\
\hline & & CV $(\%)^{2}$ & 1.89 \\
\hline \multirow{3}{*}{21} & \multirow{3}{*}{ DM $82 i 78$ ipro } & T. asperellum & 5473 a \\
\hline & & Control & $4785 b$ \\
\hline & & CV (\%) & 2.26 \\
\hline \multirow{3}{*}{22} & \multirow{3}{*}{ FTR 4288} & T. asperellum & 3957 a \\
\hline & & Control & $3653 b^{\prime}$ \\
\hline & & CV (\%) & 1.54 \\
\hline \multirow{3}{*}{23} & \multirow{3}{*}{$\begin{array}{c}\text { DM 82i78 ipro } \\
\text { ipro }\end{array}$} & T. asperellum & 4655 a \\
\hline & & Control & $4211 b$ \\
\hline & & CV (\%) & 2.94 \\
\hline \multirow{3}{*}{24} & \multirow{3}{*}{ N 7660} & T. asperellum & $4252 a$ \\
\hline & & Control & $3911 b$ \\
\hline & & CV (\%) & 0.89 \\
\hline \multirow{3}{*}{25} & \multirow{3}{*}{ M 8644 ipro } & T. asperellum & 3280 a \\
\hline & & Control & $2806 \mathrm{~b}$ \\
\hline & & CV (\%) & 1.71 \\
\hline \multirow{3}{*}{26} & \multirow{3}{*}{ M 8644 ipro } & T. asperellum & $2956 a$ \\
\hline & & Control & $2634 b$ \\
\hline & & CV (\%) & 2.63 \\
\hline \multirow{3}{*}{27} & \multirow{3}{*}{ LG 601777} & T. asperellum & 3398 a \\
\hline & & Control & $3059 \mathrm{~b}$ \\
\hline & & CV (\%) & 1.69 \\
\hline \multirow{3}{*}{28} & \multirow{3}{*}{ Bonus } & T. asperellum & 3699 a \\
\hline & & Control & $3357 b$ \\
\hline & & CV (\%) & 2.09 \\
\hline \multirow{3}{*}{29} & \multirow{3}{*}{ Challenge } & T. asperellum & 3645 a \\
\hline & & Control & $3009 \mathrm{~b}$ \\
\hline & & CV (\%) & 2.94 \\
\hline \multirow{3}{*}{30} & \multirow{3}{*}{ Extrema } & T. asperellum & 3006 a \\
\hline & & Control & $2322 b$ \\
\hline & & CV (\%) & 4.45 \\
\hline \multirow{3}{*}{31} & & T. asperellum & 3675 a \\
\hline & Bonus & Control & $3119 b$ \\
\hline & & CV (\%) & 2.97 \\
\hline & & T. asperellum & 2891 a \\
\hline 32 & M 8644 irpo & Control & $2557 b$ \\
\hline & & CV (\%) & 6.33 \\
\hline & & T. asperellum & 3972 a \\
\hline 33 & M 8644 irpo & Control & $3591 b$ \\
\hline & & CV (\%) & 1.34 \\
\hline & & T. asperellum & 4464 a \\
\hline 34 & TMG 1180 & Control & $4126 \mathrm{~b}$ \\
\hline & & CV (\%) & 1.32 \\
\hline & & T. asperellum & 3585 a \\
\hline 35 & Challenge & Control & $3339 b$ \\
\hline & & CV (\%) & 1.71 \\
\hline
\end{tabular}

'Means followed by the same small letter, in the columns, for each location/experiment, do not differ between themselves by the $\mathrm{F}$ test at $5 \% .{ }^{2}$ Coefficient of variation.

Some authors have reported positive results with Trichoderma inoculation in soybean, like Chagas et al. (2017a), Gonçalves et al. (2018) and Chagas Junior et al. (2019a, b) who concluded that Trichoderma acts as a promoter of vegetable growth positively affecting biomass and soybean productivity. 
Plants containing this microorganism associated with their roots or in the rhizosphere tend to improve their ability to survive and absorb nutrients in adverse situations. Consequently, these plants have a productive advantage over those with an absence of Trichoderma in their roots (Contreras-Cornejo et al., 2016).

Some of the factors that determine the success of Trichoderma inoculation include abiotic and biotic conditions. Therefore, selected isolates to compose inoculants and formulations need to be able to produce satisfactory results under field conditions with the ability to promote vegetable growth, resulting in increased productivity. This is related to the fact that establishment and development under field conditions are critical for the microorganism because they are exposed to different reactions from the host and the environment, which can result in more effective control or promotion of a more variable vegetable growth than can be achieved with chemicals. In the current study, the use of T. asperellum 201 showed significant results regarding the productivity of the different cultivars in the different regions and provided results regarding the benefits for soybean growing areas with the use of this formulation in soybean seed inoculation.

These positive responses in soybean yield in different regions may be related to adaptation to specific biotic and abiotic conditions, from which the isolate T. asperellum 201 was isolated. Factors such as temperature, soil type, aeration, $\mathrm{pH}$, humidity, and nutrients interfere in the development of fungi of this genus (Silva et al., 2020). Thus, bioagents collected in the same environment or under similar climatic conditions as where they will be used are more likely to adapt and be more effective.

The experiments, in different regions and crops, showed the positive effect of the product containing $T$. asperellum with potential as a vegetable growth promoter, and targeting for use of inoculant in this powder formulation, as a vegetable growth promoter inoculant in strategic crops such as soybeans, according to the results of this research, achieving new areas in potential for the use of the product (inoculants).

The use of the product, with active ingredient based on T. asperellum 201 as a plants growth promoter, to increase agricultural production will probably be one of the most important strategies for the agricultural sector. This is due to the emerging demands for reducing the dependence on chemical fertilizers, in addition to pesticides, and the need for sustainable agricultural development.

The results showed in the present study demonstrate that this fungus, a promoter of vegetable growth, presents itself as a technology for soybean cultivation and the effect on productivity. Thus, this microorganism, used as a growth-promoting inoculant, could have an important impact in achieving sustainable agriculture and protecting the environment, as well as the formulation, in the ease of application in the treatment of soybean seeds.

These effects of Trichoderma as a vegetable growth promoter have also been reported for other crops, as for example, it has been reported that the treatment of rice, wheat and tomato seeds with Trichoderma increases the photosynthetic rate, the weight of the plants, the length of their roots and shoots and the number of leaves and leaf area (Domínguez et al, 2016), as well as in the biomass increment of maize (Chagas et al., 2017b), tomato (Rubio et al., 2017), papaya (Chagas Junior et al., 2020), rice (Chagas et al., 2017a,b; Silva et al., 2019) and cowpea Chagas et al., 2016).

The benefits of the ecological processes performed by fungi of the genus Trichoderma as a plant growth promoter have contributed to achieving sustainability in the agricultural sector. The technology of inoculation of microorganisms, such as the fungus Trichoderma, of biotechnological interest in agriculture is a resource of major economic importance, besides the contribution to reducing the use and consequent impact of agrochemicals. Sustainable agriculture requires the use of strategies that allow for an increase in productivity without damaging the environment, opening new perspectives to contribute to the development of new technologies, methods, and strategies in agribusiness. The processes mediated by microorganisms become essential in the preservation and conservation of natural resources.

\section{Conclusions}

The inoculation of soybean with the product in this formulation containing Trichoderma asperellum 201, in the dosage of $5 \mathrm{~g}$ per $\mathrm{kg}$ of seed, showed an increase in the productivity of soybean cultivated in the different regions in the states of Bahia and Tocantins.

The product, with an active ingredient based on $T$. asperellum 201, can be recommended as an inoculant plant growth promoter for soybeans.

\section{Compliance with Ethical Standards}

Author contributions: Conceptualization: AFCJ, LFBC; Formal analysis: AFCJ, LFBC, ALLM, BSOC, RSO; Funding acquisition: AFCJ; Investigation: AFCJ, LFBC, ALLM, BSOC, RSO; Methodology: AFCJ, LFBC, ALLM, BSOC, RSO; Resources: AFCJ, LFBC, ALLM, BSOC, RSO; Supervision: AFCJ; Writing original draft: AFCJ, LFBC, ALLM, BSOC, RSO; Writing - review \& editing: AFCJ, LFBC.

Conflict of interest: The authors declare that there are no conflicts of interest.

Financing source: The Coordenação de Aperfeiçoamento de Pessoal de Nível Superior (CAPES) - Finance Code 001, the Fundação de Apoio Científico e Tecnológico do Tocantins (FAPTO), and the Conselho Nacional de Desenvolvimento Científico e Tecnológico (CNPq).

\section{Literature Cited}

Agritempo. Sistema de monitoramento agrometeorológico. http:// www.agritempo.gov.br. 25 Aug. 2021. 
Alekseeva, K.L.; Smetanina, L.G.; Kornev, A.V. Biological protection of tomato from Fusarium wilt. AIP Conference Proceedings, v.2063, n. 1, e030001, 2019. https://doi.org/10.1063/1.5087309.

Bernardo, J.T.; Aguilera, J.G.; Silva, R.B.; Medeiros, I.R.E.; Vian, R.; Niella, G.R.; Ulhoa, C.J. Isolamento on farm de Trichoderma: uma ferramenta no controle de doenças de solo para os agricultores no Brasil. Revista Eletrônica Científica da UERGS, v.5, n.3, p.263270, 2019. https://doi.org/10.21674/2448-0479.53.263-270.

Bononi, L.; Chiaramonte, J.B.; Pansa, C.C.; Moitinho, M.A.; Melo, I.S. Phosphorus-solubilizing Trichoderma spp. from Amazon soils improve soybean plant growth. Scientific Reports, v.10, n.2858, p.1-13, 2020. https://doi.org/10.1038/s41598-020-59793-8.

Brazil. Ministério da Agricultura, Pecuária e Abastecimento - Mapa. Instrução normativa № 1, de 02 de fevereiro de 2012. Especifica, para fins de indicação das cultivares de soja no Zoneamento Agrícola de Risco Climático do Ministério da Agricultura, Pecuária e Abastecimento, as macrorregiões sojícolas e respectivas regiões edafoclimáticas, na forma da relação anexa. Diário Oficial da União, v.149, n.27, seção 1, p.7-9, 2012a.

Brazil. Ministério da Agricultura, Pecuária e Abastecimento - Mapa. Instrução normativa № 1, de 02 de fevereiro de 2012. Especifica, para fins de indicação das cultivares de soja no Zoneamento Agrícola de Risco Climático do Ministério da Agricultura, Pecuária e Abastecimento, as macrorregiões sojícolas e respectivas regiões edafoclimáticas, na forma da relação anexa. Diário Oficial da União, v.149, n.28, seção 1, p.2-5, 2012b.

Chagas, L.F.B.; Colonia, B.S.O.; Santos, G.R.; Scheidt, G.N.; Portella, A.C.F.; Soares, L.P.; Chagas Junior, A.F. Rice growth influence by Trichoderma spp. with natural phosphate fertilization under greenhouse conditions. International Journal of Development Research, v. 7, n. 6, p. 13147-13152, 2017c. https://www.journalijdr.com/sites/ default/files/issue-pdf/8761.pdf. 21 Apr. 2021.

Chagas Junior, A.F.; Chagas, L.F. B.; Miller, L.O.; Oliveira, J.C. Efficiency of Trichoderma asperellum UFT 201 as plant growth promoter in soybean. African Journal of Agricultural Research, v.14, n.5, p.263-271, 2019a. https://doi.org/10.5897/AJAR2018.13556.

Chagas Junior, A.F.; Chagas, L.F.B.; Colonia, B.S.O.; Miller, L.O.; Oliveira, J.C. Trichoderma asperellum (UFT201) functions as a growth promoter for soybean plant. African Journal of Agricultural Research, v. 14, n. 33, p. 1772-1777, 2019b. https:// doi.org/10.5897/AJAR2019.13985.

Chagas Junior, A.F.; Martins, A.L.; Nóbrega, G.S.; Silva, T.G.C.; Chagas, L.F.B. Trichoderma ssp. como promotor de crescimento de mudas de mamão. In: Francisco, P.R.M.; Ribeiro, G.N.; Medeiros, P.C. (Org.). Ciência, Desenvolvimento e Inovação na Engenharia e Agronomia Brasileira. Campina Grande: EPGRAF, 2020. v.4, p.70-74.

Chagas, L.F.B.; Chagas Junior, A.F.; Soares, L.P.; Fidelis, R.R. Trichoderma na promoção do crescimento vegetal. Revista de Agricultura Neotropical, v.4, n.3, p.97-102, jul./set. 2017b. https://doi.org/10.32404/rean.v4i3.1529.

Chagas, L.F.B.; Castro, H.G.; Colonia, B.S.O.; Carvalho Filho, M.R.; Miller, L.O.; Chagas Junior, A.F. Efficiency of the inoculation of Trichoderma asperellum UFT-201 in cowpea production components under growth conditions in field. Revista de Ciências Agrárias, v.39, n.3, p.413-421, 2016. https://doi.org/10.19084/ RCA15112.
Chagas, L.F.B.; Chagas Junior, A.F.; Castro, H.G. Phosphate solubilization capacity and indole acetic acid production by Trichoderma strains for biomass increase on basil and mint plants. Brazilian Journal of Agriculture, v.92, n.2, p.176-185, 2017a. https://doi.org/10.37856/bja.v92i2.3221.

Companhia Nacional de Abastecimento - Conab. Acompanhamento da safra brasileira grãos. Brasília: Conab, 2018. 178p. (v. 5 - safra 2017/18, n.10, décimo levantamento. https://www.conab.gov. br/info-agro/safras/graos/boletim-da-safra-de-graos/item/ download/21088_8ca248b277426bb3974f74efa00abab6. 16 May. 2021.

Contreras-Cornejo, H.A.; Macías-Rodríquez, L.; Del-Val, E.; Larsen, J. Ecological functions of Trichoderma spp. and their secondary metabolites in the rhizosphere: interactions with plants. FEMS Microbiology Ecology, v.92, n.4, p.1-17, 2016. https://doi. org/10.1093/femsec/fiw036.

Das, T.; Mahapatra, S.; Das, S. In vitro compatibility study between the Rhizobium and native Trichoderma isolates from lentil rhizospheric soil. International Journal of Current Microbiology and Applied Sciences, v.6, n.8, p.1757-1769, 2017. https://doi. org/10.20546/ijcmas.2017.608.208.

Domínguez, S.; Rubio, M.B.; Cardoza, R.E.; Gutiérrez, S.; Nicolás, C.; Bettiol, W.; Hermosa, R.; Monte, E. Nitrogen metabolism and growth enhancement in tomato plants challenged with Trichoderma harzianum expressing the Aspergillus nidulans acetamidase amdS gene. Frontiers in Microbiology, v. 7, e1182, 2016. https://doi.org/10.3389/fmicb.2016.01182.

Empresa Brasileira de Pesquisa Agropecuária - Embrapa. Matopiba. https://www.embrapa.br/tema-matopiba. 13 May 2021.

Ferreira, D.F. Sisvar: a computer analysis system to fixed effects split plot type designs. Revista Brasileira de Biometria, v.37, n.4, p.529-535, 2019. https://doi.org/10.28951/rbb.v37i4.450.

Ferreira, L.B.S. Avaliação de Trichoderma harzianum super expressando o gene de aquaporina para o controle de Meloidogyne javanica em feijão comum. Urutaí: Instituto Federal Goiano, Campus Urutaí, 2018. 27p. Master Thesis. https://repositorio.ifgoiano.edu.br/handle/prefix/306. 10 May. 2021.

Gonçalves, A.H.; Chagas, L.F.B.; Santos, G.R.; Fidelis, R.R.; Filho, M.R.C.; Miller, L.O.; Chagas Junior, A.F.C. Trichoderma efficiency in the maintenance and productivity of soybeans plants in producing savanna regions, Tocantins, Brazil. Revista de Ciências Agrárias, v.41, n.1, p.175-181, 2018. https://doi.org/10.19084/ RCA17079.

Henning, A. A. Manejo de doenças da soja (Glycine max L. Merrill). Informativo ABRATES, v.19, n.3, p.9-12, 2009.

Instituto Nacional de Meterorologia - Inmet. Dados meteorológicos. Mapa das estações. https://mapas.inmet.gov.br/. 09 Apr. 2021.

Input. Regiões. Matopiba. https://www.inputbrasil.org/regioes/ matopiba. 13 May 2021

Karaoglu, S.A.; Bozdeveci, A.; Pehlivan, N. Characterization of Local Trichoderma sp. as Potential Bio-Control Agents, Screening of in vitro Antagonistic Activities and Fungicide Tolerance. Hacettepe Journal of Biology and Chemistry, v. 46, n. 2, p. 247-261, 2018. https://doi.org/10.15671/HJBC.2018.233. 
Mendoza-Mendoza, A.; Zaid, R.; Lawry, R.; Hermosa, R.; Monte, E.; Horwitz, B.A.; Mukherjee, P.K. Molecular dialogues between Trichoderma and roots: role of the fungal secretome. Fungal Biology Reviews, v.32, n.2, p.62-85, 2018. https://doi. org/10.1016/j.fbr.2017.12.001.

Monte, B.H.; Bettiol, E.; Hermosa, R. Trichoderma e seus mecanismos de ação para o controle de doenças de plantas. In: Meyer, M.C.; Mazaro, S.M.; Silva, J.C. (Eds.). Trichoderma: uso na agricultura. Brasília: Embrapa, 2019. p.181-199.

Murillo-Cuevas, F.D.; Adame-García, J.; Cabrera-Mireles, H.; Fernandez-Viveros, J.A. Fauna y microflora edáfica asociada a diferentes usos de suelo. Ecosistemas y Recursos Agropecuarios, v.6, n.16, p.23-33, 2019. https://doi.org/10.19136/era. a6n16.1792.

Pascholati, S.F.; Souza, V.H.M.; Filho, J.A.C. Indução de resistência por Trichoderma. In: Meyer, M.C.; Mazaro, S.M.; Silva, J.C. (Eds.). Trichoderma: uso na agricultura. Brasília, DF: Embrapa, 2019. p.235-252.

Ramada, M.H.S.; Lopes, F.A.C.; Ulhoa, C.J. Trichoderma: metabólitos secundários. In: Meyer, M.C.; Mazaro, S.M.; Silva, J.C. (Eds.). Trichoderma: uso na agricultura. Brasília: Embrapa, 2019. p.2012018.
Rubio, M.B.; Hermosa, R.; Vicente, R.; Gómez-Acosta, F.A.; Morcuende, R.; Monte, E.; Bettiol, W. The combination of Trichoderma harzianum and chemical fertilization leads to the deregulation of phytohormone networking, preventing the adaptive responses of tomato plants to salt stress. Frontiers in Plant Science, v.8, e294, 2017. https://doi.org/10.3389/fpls.2017.00294.

Silva, G.B.; Rêgo, M.C. F.; França, S.K.S.; Sousa, T.P.; Nascente, A.S.; Lanna, A.C.; Filippi, M.C.C.; Souza, A.C.A.; Andrade, G.B. Uso do Trichoderma na cultura do arroz. In: Meyer, M.C.; Mazaro, S.M.; Silva, J.C. (Eds.). Trichoderma: uso na agricultura. Brasília: Embrapa, 2019. p.349-360.

Silva, H.F.; Santos, A.M.G.; Amaral, A.C.T.; Bezerra, J.L.; Luz, E.D.M.N. Bioprospection of Trichoderma spp. originating from a CerradoCaatinga ecotone on Colletotrichum truncatum, in soybean. Revista Brasileira de Ciências Agrárias, v. 15, n. 1, e7680, 2020. https://doi.org/10.5039/agraria.v15i1a7680.

Souza, K.A.; Bittencourt, G.M. Avaliação do crescimento das exportações brasileiras de soja em grão. Revista de Política Agrícola, v. 28, n.4, p. 48-67, 2019. https://seer.sede.embrapa. br/index.php/RPA/article/view/1462/pdf. 03 May 2021.

Woo, S.L.; Pepe, O. Microbial consortia: promising probiotics as plant biostimulants for sustainable agriculture. Frontiers in Plant Science, v. 9, e1801, 2018. https://doi.org/10.3389/fpls.2018.01801. 